Article

\title{
National Sustainability Outreach Assessment Based on Human and Social Capital: The Case of Environmental Sciences in Switzerland
}

\author{
Harald A. Mieg ${ }^{1, *}$, Ralph Hansmann ${ }^{2}$ and Peter M. Frischknecht ${ }^{2}$
}

1 Institute of Geography, Humboldt-Universität zu Berlin, Unter den Linden 6,

Berlin D-10099, Germany

2 Department of Environmental Sciences, Swiss Federal Institute of Technology Zurich, ETHZ CHN, Universitätsstrasse 8, Zurich CH-8092, Switzerland; E-Mails: ralph.hansmann@env.ethz.ch (R.H.); peter.frischknecht@env.ethz.ch (P.M.F.)

* Author to whom correspondence should be addressed; E-Mail: harald.mieg@geo.hu-berlin.de; Tel.: +49-30-2093-6892; Fax: +49-30-2093-6835.

Received: 11 October 2011; in revised form: 21 November 2011 / Accepted: 12 December 2011 / Published: 28 December 2011

\begin{abstract}
This paper reports on a sustainability outreach study based on an assessment of human and social capital. The aim was to capture the national sustainability outreach of twenty years of Environmental Sciences education, centered at the Swiss Federal Institute of Technology (ETH) in Zurich. The study contained two lines of research, one being a human capital assessment with a survey among graduates from the years 1992 to 2005 $(n=542)$ and the other being a social capital analysis based on interviews with institutions that represent the Swiss social systems of economy, politics/public administration and civil society (20 institutions). Our analyses reveal several functional forms of both human capital (specialists, pioneers, leaders) and social capital (qualification profile, internalization, networks, standardization, professionalization) that trigger and channel sustainability outreach.
\end{abstract}

Keywords: sustainability outreach; environmental sciences; human capital; social capital 


\section{Introduction: Human and Social Capital}

Since the 1990s, the OECD has been researching and promoting the concepts of human and social capital. Both concepts are more or less linked to the education system. In particular human capital is defined via individual knowledge [1] and measured via educational attainment [2]. Based on a review of the human capital literature, the OECD report of 1996 defined human capital "as the knowledge that individuals acquire during their life and use to produce goods (,) services or ideas in market or non-market circumstances" (p. 22) [1]. The current OECD short definition reads as follows: "Human capital is productive wealth embodied in labour, skills and knowledge" [3]. This definition gives credit to the fact that human capital "can be now identified as a key factor in economic production" (p. 9) [2]. Given the important role of human capital for productivity, it comes as no surprise that the development of human capital can also be considered a necessary condition for "long-term sustainability" [4].

Whereas human capital refers to skilled individuals with "a focus directly on what it is that individuals bring to work and economic activity" [2], social capital refers to social institutions [5,6]. Putnam [6] related social capital to "features of social organization such as networks, norms, and social trust that facilitate coordination and cooperation for mutual benefit". Accordingly, the OECD defines social capital through norms and social relations: "Social capital is defined as the norms and social relations embedded in the social structures of societies that enable people to co-ordinate action to achieve desired goals" [7]. The integration of research on human and social capital is considered a new challenge: "Recent research has improved our understanding of how education not only produces human capital, but also contributes to wider social benefits. Human capital and social capital interact in improving not only labor market outcomes, but also health, civic participation, political engagement, trust and tolerance" [8].

We used the concepts of human and social capital for the assessment of the outreach of twenty years of the Environmental Sciences educational program at the Swiss Federal Institute of Technology in Zurich. As the program is based on the principles of sustainable development, the focus of the outreach assessment was on its sustainability impact. What was - in terms of human and social capital - the contribution of the Environmental Sciences educational program to sustainability in Switzerland? What does this case teach us about functional forms of human and social capital of sustainability outreach in general?

For an operationalization, we followed the approach of expertise as human capital $[9,10]$. Social capital was assessed within a social systems approach [11]. For our outreach study, we combined quantitative and qualitative methods. We found that besides the "production" of skilled people—or human capital [4] - a major part of the outreach of Environmental Sciences education in Switzerland rested on increased social capital, namely the definition and proliferation of standards for understanding human-environmental systems. However, we also found a divide between the public perception of the educational program and that of the conducted research by ETH Environmental Sciences. 


\section{The Swiss Context of Education in Environmental Sciences}

In the following we will present the context of the outreach study, that is the educational program in Environmental Sciences at ETH Zurich in general and the 2009 sustainability impact study in particular.

\subsection{The Environmental Sciences Educational Program at ETH Zurich}

Switzerland has a long tradition of integrating environmental issues within society. One driving concern has been water management. In 1888 a Swiss law protecting fish populations was approved. In 1936, an advisory centre for wastewater treatment und drinking water supply was established at the Swiss Federal Institute of Technology, Zurich (ETH). In the 1940s, the first professional association for ecological water engineering was founded. A further milestone was set by the Water Protection Law of 1955 (Gewässerschutzgesetz). Environmental issues were also integrated within the 1983 Environmental Protection Law (Umweltschutzgesetz), the main body of Swiss environmental law that has since become one of the few core federal domains in Switzerland [12]. The Swiss discourse on environmental protection culminated when sustainability became a constitutional goal in 1999, by which an integration of environmental, economic and social issues in Swiss society and a responsible use of resources are stipulated [13].

A result of this enduring public discussion on ecological issues, as well as the occurrence of accidents such as Chernobyl and particularly Schweizerhalle, both in 1986, was the introduction of the Environmental Sciences curriculum at the ETH Zurich (Eidgenössische Technische Hochschule/Swiss Federal Institute of Technology), the federal university of Switzerland. The lack of and need for experts in analyzing, understanding and handling such problems motivated this step [14,15]. The new educational program started in 1987 and was intended to be practice-oriented and based on a systems view [16]. The curriculum comprised of the following:

- A basic training in mathematics and all major natural sciences was followed by an interdisciplinary education with a focus on a specific natural system such as atmosphere or aquatic and terrestrial systems.

- Mandatory classes in economics, environmental law, social sciences and environmental technology addressed the interactions between nature and society.

- A new didactic approach — namely, the transdisciplinary case study — was introduced to teach sustainability learning and to realize science-society cooperation by integrating ecological aspects and a systems view in processes of urban and regional development [17].

- Finally, a compulsory internship near the end of the program aimed to further enhance the students' skills in cooperation and implementation [18].

The first guide for the educational program of 1989-just before the sustainability concept was spread worldwide - defined the educational goal as "a new type of natural scientist," both specialist and generalist who knows how to talk to and cooperate with farmers, engineers, public administration and politicians [19]. Since the 1990s, sustainability has explicitly become the educational goal of the ETH Environmental Sciences: "The focus lies on incorporating sustainability, with the goal of applying this concept into future professional activities" [20]. Already in 1997, this educational program was internationally perceived as an example of incorporating "value" (sustainability) into science [21]. 
Though there is a focus on environmental issues in the ETH Environmental Sciences educational program, sustainability is always taught and practiced from an integrative perspective. Through the mandatory transdisciplinary case studies, the Environmental Sciences students have become an active part of initiatives for sustainable development in half of Switzerland, in rural regions, faced with the problem of defining new, sustainability-oriented roles of farmers [22], as well as in cities, dealing for instance with the economics of the revitalization of industrial sites [23]. The 1995 transdisciplinary case study [24] was part of the development of Zurich West, today one of Switzerland's most prominent examples for sustainable urban development. Meanwhile, the case studies' approach of the ETH Environmental Sciences has been cast into a methodology of sustainability learning in higher education [25,15]. Today, several universities in Europe-like the ETH Environmental Sciences educational program - undertake sustainability science partnerships with external public-private and civil sectors agents [26].

\subsection{The ETH Sustainability Impact Study 2009}

From its onset, a comprehensive quality control and evaluation of the success of the curriculum of Environmental Sciences was considered essential. A continual evaluation system was implemented [14] and further supplemented through various other specific evaluation projects running in parallel. In 2009 the evaluative studies were adjusted under a new overarching framework meant to cover both the output of the educational program and its sustainability impact in Switzerland [27].

This encompassing evaluation approach was consistent with the aims of the founders of the program, who considered it to be a crucial step towards a more sustainable development in Switzerland. The distinctive denotation and character of the program, which distinguishes the Environmental Sciences graduates in civil society and the labor market, as well as the attributes of the country-i.e., being rather small, confined and with considerable independence-were factors suggesting that societal sustainability impacts can indeed be evaluated by a combination of quantitative and qualitative methods capturing multiple perspectives.

In 2009 a sustainability impact study was launched in order to assess the specific outreach of the Environmental Sciences educational program of ETH Zurich. The impact was analyzed across the two categories of human and social capital by using a combination of two methodologically different approaches, a quantitative survey and a qualitative interview study (see Figure 1). On the one hand, this allowed to test hypotheses regarding human capital with a large, representative sample, while on the other hand, the open ended nature of qualitative research [28] was seen as a necessity for discovering social capital in the new field of sustainability education $[26,29,30]$. 
Figure 1. Design of the outreach study.

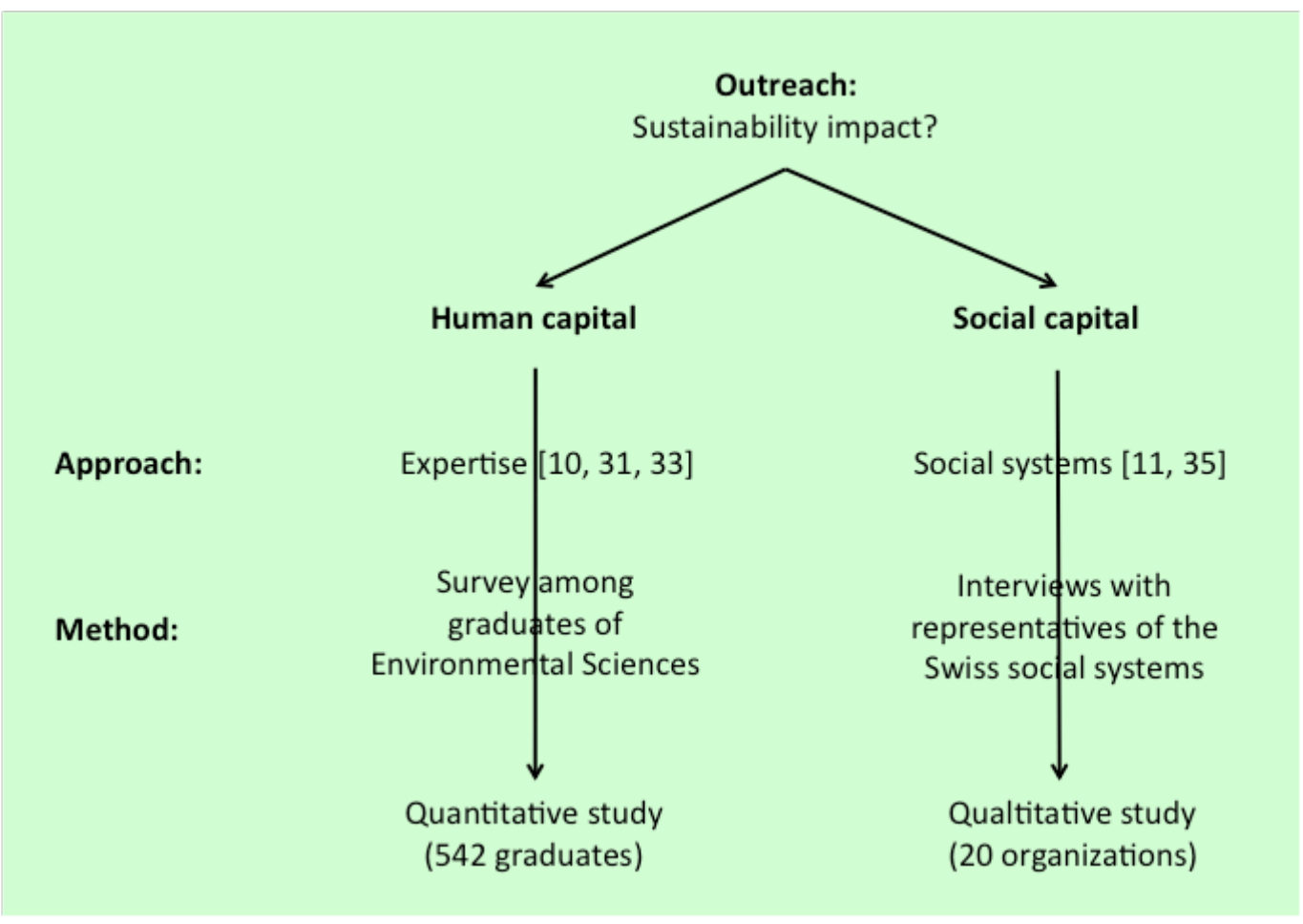

\section{Quantitative Study: Human Capital Assessment}

The following section reports on the approach and results of the quantitative part of the sustainability impact study.

\subsection{General Approach}

Expertise can be considered a form of human capital $[9,10]$, as it refers to specific skills and knowledge and results from intensive training and pro-longed education [31]. Expertise is highly domain-specific and difficult to transfer [31]. Therefore, many scholars [32] have suggested analyzing professional expertise only in the context of application. As Mieg [33] has shown, we have to distinguish two factors of expertise related to professional work: expertise as excellence and expertise as professionalism. Expertise as excellence becomes most effective in its own domain, working with already established standards. In contrast, expertise as professionalism is about establishing new standards in a new or foreign professional field.

Thus, to study human capital in the form of expertise, we have to consider the interaction of degree of expertise and particular professional fields. This delivers two types of human capital, here defined as types of experts:

(1) Experts in an established professional field-specialists.

(2) Experts in a new or foreign professional field-pioneers. 
In order to also take into account varying degrees of expertise, the top experts - usually the top $10 \%$ performers of a domain -were studied as a third type of human capital. As there is no unique performance measure for advancing sustainability, we focused on organizational positions:

(3) Top experts - leaders, holding the highest managerial positions in their organizations.

Unfortunately, we lack any quantification for sustainability-related human capital. We therefore established criteria and hypotheses to help assess the sustainability impact of ETH Environmental Sciences on Swiss society with regard to the contribution to human capital, i.e., the impacts triggered by graduates as sustainability experts. The criteria were:

(1) High degree of penetration of Swiss society: In general, graduates should contribute as specialists to sustainability in many societal sectors or professional fields.

(2) Pioneering work: Even in industries or sectors that are generally not linked to sustainability concerns, graduates should be active as sustainability pioneers.

(3) Influence: Even graduates holding top managerial positions should actively contribute to sustainable development. For graduates of Environmental Science, taking leadership roles in companies should not involve a disconnection from ideas about sustainable development.

These criteria can be directly transformed into hypotheses related to the three types of human capital or experts previously introduced.

\subsection{Hypotheses: Specialists, Pioneers and Leaders}

The first hypothesis concerns the graduates as sustainability specialists in the Swiss society. The Specialists Hypothesis contains three parts:

(1) The graduates are professionally active in (i) a reasonable number of professional fields; (ii) small, medium-sized and large organizations; and (iii) all sectors of Swiss society.

(2) In general, the graduates are somehow concerned with sustainability in their professions.

(3) If someone is professionally engaged in sustainability, his/her engagement increases throughout their career.

This first hypothesis also reacts to doubts regarding the employability of graduates of Environmental Sciences that accompanied the introduction of this education program from its inception [27]. It was feared that the educational profile would be too narrow and that the leading big industries in Switzerland such as banking or chemical industry would not be interested in such specialists. Therefore, test criteria for part (1) of the hypothesis - concerning the penetration of the Swiss labor market-were: (i) the main three fields of professional activity (particularly employment by universities and small planning offices) should not exceed $50 \%$ of all activities; (ii) employment in small organizations ( $<50$ employees) should not exceed 50\%; and (iii) no single societal sector should contribute $50 \%$ or more to the professional activities of graduates of ETH Environmental Sciences.

The second hypothesis refers to pioneering work by graduates of the ETH Environmental Sciences in the three professional fields that would turn out to be generally weakly related to sustainability (see Table 1). Under the Pioneers Hypothesis, we examine the engagement of graduates as active sustainability pioneers as follows: 
(1) Even in professional fields with low sustainability we will find graduates whose work is (considerably) related to sustainability.

(2) These graduates have an increased influence on sustainability concerns in their organizations in the course of their careers.

The third hypothesis refers to managerial leadership and influence. We do not expect that graduates holding top managerial positions are generally also top sustainability experts. However, we might expect that they bring in their specific human capital and promote sustainability in a substantial way. In this context, we must also clarify whether this contribution is still seen as linked to their academic education in Environmental Sciences. Accordingly, the Leaders Hypothesis contains two parts:

(1) Graduates who now hold top managerial positions promote sustainability in a substantial way.

(2) In addition, these people assess their academic education as particularly useful.

Table 1. Fields of professional activity. Fields with low ratings $(<2.5$, negative pole of the Likert scale) of the relatedness of professional activities to sustainability are shaded.

\begin{tabular}{lccccc}
\hline & & \multicolumn{2}{c}{$\begin{array}{c}\text { Relatedness to } \\
\text { Percentage }\end{array}$} & \multicolumn{2}{c}{$\begin{array}{c}\text { Work time devoted to } \\
\text { sustainability }\end{array}$} \\
\cline { 3 - 6 } & $\left(\sum=\mathbf{5 2 4}\right)$ & Mean & $\begin{array}{c}\text { Standard } \\
\text { error of mean }\end{array}$ & $\begin{array}{c}\text { Mean } \\
\text { (\%) }\end{array}$ & $\begin{array}{c}\text { Standard } \\
\text { error of mean }\end{array}$ \\
\hline Environmental-, planning-, & & & & 62 & 3.3 \\
engineering office & $15.1 \%$ & 3.7 & 0.1 & & 4.1 \\
Public administration & $14.9 \%$ & 3.4 & 0.1 & 54 & 4.1 \\
Universities & $13.4 \%$ & 2.7 & 0.2 & 30 & 5.3 \\
Banks/Insurances & $9.9 \%$ & 2.2 & 0.2 & 25 & 4.3 \\
Education & $8.2 \%$ & 2.6 & 0.2 & 27 & 5.4 \\
Research outside universities & $7.4 \%$ & 3.3 & 0.1 & 45 & 5.7 \\
Environmental NGOs & $5.0 \%$ & 4.0 & 0.2 & 75 & 9.0 \\
Consulting & $3.8 \%$ & 2.8 & 0.3 & 41 & 9.1 \\
Health sector & $3.3 \%$ & 2.4 & 0.3 & 26 & 9.3 \\
Energy/water supply & $2.5 \%$ & 4.2 & 0.3 & 79 & 10.8 \\
Other industry & $2.1 \%$ & 3.3 & 0.5 & 47 & 12.5 \\
Transport & $1.9 \%$ & 3.2 & 0.5 & 55 & 13.2 \\
Media & $1.7 \%$ & 2.8 & 0.5 & 37 & 9.2 \\
Chemical industry & $1.7 \%$ & 3.3 & 0.4 & 38 & 17.8 \\
Commerce & $1.1 \%$ & 3.7 & 0.7 & 58 & 9.3 \\
Agriculture, forestry & $1.0 \%$ & 3.8 & 0.4 & 84 & 10.7 \\
Construction industry & $1.0 \%$ & 3.2 & 0.4 & 49 & 5.7 \\
Other public services & $4.0 \%$ & 2.0 & 0.3 & 14 & 1.9 \\
Others & $2.1 \%$ & 2.7 & 0.4 & 34 & 44 \\
Total & $100 \%$ & 3.1 & 0.1 & 4 & \\
\hline
\end{tabular}

* Rating scale: $1=$ no, $2=$ rather no, $3=$ rather yes, $4=$ yes, to $5=$ yes, very strongly. 


\subsection{Methods and Samples}

The study used a web-based survey on the careers of the graduates of Environmental Sciences from 1992 to 2005 and their sustainability contributions. Graduates from this time span were invited via e-mail to take part in the survey, which was available online throughout October 2009. The survey mainly elicited self-assessments and covered in particular:

- Professional activities since graduation (e.g., income, position, size of company/organization, field of activities);

- The degree of engagement towards sustainability through these professional activities in general and by means of specific best practice examples.

For the items of this survey we generally used a five-point bipolar "Likert" scale. For instance, we asked the graduates whether they experienced an advantage or disadvantage in their professional activities as compared to graduates of more specialized university programs (scale from $1=$ clear disadvantage to $3=$ balanced to $5=$ clear advantage). Two items were included to assess the relation of the professional activities to sustainability. One item asked for the strength of the relatedness of the professional activity to sustainability on a scale from 1 (= no) to 5 (= yes, very strongly), and the second item asked for an estimate of the percentage of work-time devoted to sustainability oriented activities.

In addition, the graduates had to describe and assess best practice examples of their own sustainability-related professional activities such as natural protection projects; sustainability teaching in secondary schools; promoting intercultural gardens in Switzerland; improving the intra-organizational health management of a big company; or the establishment of a spin-off company in the solar energy industry. For instance, the graduates were asked whether efforts for a systematic integration of ecological, economic and social aspects of sustainability were undertaken in their practice example (yes or no), whether sustainability relevant effects had been monitored or evaluated (yes or no), to which of 15 specific objectives of the Swiss sustainability strategy [34] the example contributed (15 items in yes or no format), and how strongly it promoted sustainability $(1=$ very weak to $5=$ very strong contribution).

Altogether 1081 students graduated from the Environmental Sciences program at the ETH between 1992 and 2005. 808 of these graduates could be tracked down and were invited to participate in the study. Of the invited professionals, 567 visited the survey webpage responding at least to the first question (response rate: 70.2\%), which asked whether the graduate was currently professionally active, and if so when he or she began their current job. 441 answered the complete questionnaire, representing $40.8 \%$ of the total population of graduates, 397 graduates provided one or more best practice example. The graduation years of the survey participants were distributed similarly to the graduation years of all graduates from 1992 to 2005 (Chi-Square, $\mathrm{df}=13, \mathrm{p}=0.43$ ).

Table 1 shows the various fields of professional activity of the graduates. 19 fields had a share of at least $1 \%$. More than half of the graduates work in one of the first four fields: private environmental/planning/engineering offices (15.1\%); public administration (14.9\%); universities (13.4\%); or banks and insurances $(9.9 \%)$. The table also contains the ratings by the professionals of how closely their work is related to sustainability issues and how much work time they devote to 
sustainability oriented activities. The 19 fields of professional activity differ significantly in relatedness to sustainability and work time devoted to sustainability (ANOVA, F(18,505) =6.2 and $\mathrm{F}(18,482)=7.6, p<0.001)$. Both measures are highly correlated $(\mathrm{r}=0.84, \mathrm{n}=502, p<0.001)$. In all but three fields, work is related at least moderately $(>2.5)$ to sustainability, the exceptions being banks and insurances, the health sector and other public services.

\subsection{Results}

\subsubsection{High Degree of Penetration of Swiss Society: Specialists}

As Table 1 shows, we find graduates of Environmental Sciences in at least 19 clearly different professional fields (with a share of at least 1\% each). As we see in Table 2, we find them working in organizations of all size, covering the four main societal sectors (Private Sector; Public Sector; Civil Society; Science). The three criteria mentioned in 3.2 are met: (i) the main three fields of professional activity add up to less than $45 \%$ and do not exceed $50 \%$ of all activities (cf. Table 1); (ii) employment in small organizations ( $<50$ employees) is about $35 \%$ and does not exceed $50 \%$; and (iii) no single societal sector contributes $50 \%$ or more to the professional activities. Thus the first part (1) of the Specialists Hypothesis is confirmed.

Table 2. Specialists Hypothesis: Relatedness of current professional activity to sustainability with regard to professional sectors and size of organization.

\begin{tabular}{|c|c|c|c|c|c|c|}
\hline & \multicolumn{3}{|c|}{ Relatedness to sustainability $^{a}$} & \multicolumn{3}{|c|}{ Work time devoted to sustainability } \\
\hline & Mean & $\begin{array}{c}\text { Standard } \\
\text { error of mean }\end{array}$ & $\mathbf{n}$ & $\begin{array}{c}\text { Mean } \\
(\%)\end{array}$ & $\begin{array}{c}\text { Standard } \\
\text { error of mean }\end{array}$ & $\mathbf{n}$ \\
\hline \multicolumn{7}{|l|}{ Size of organization } \\
\hline Less than 10 employees & $3.3 * *$ & 0.1 & 88 & 51 & 4.0 & 83 \\
\hline 10-49 employees & $3.4 * *$ & 0.1 & 103 & 52 & 3.7 & 95 \\
\hline 50-99 employees & $2.9 * *$ & 0.2 & 57 & 46 & 4.9 & 55 \\
\hline 100-249 employees & 2.7 & 0.2 & 63 & 35 & 4.8 & 57 \\
\hline 250-999 employees & $3.2 * *$ & 0.1 & 87 & 45 & 4.1 & 79 \\
\hline $\begin{array}{l}1000 \text { or more } \\
\text { employees }\end{array}$ & $2.8 *$ & 0.1 & 142 & 38 & 3.2 & 130 \\
\hline \multicolumn{7}{|l|}{ Societal Sector } \\
\hline Private Sector & $3.0 * *$ & 0.1 & 250 & 45 & 2.4 & 240 \\
\hline Public Sector & $3.0 * *$ & 0.1 & 134 & 43 & 3.3 & 126 \\
\hline Civil Society: NGOs & $3.8 * *$ & 0.2 & 40 & 63 & 5.4 & 40 \\
\hline Science & $3.0 * *$ & 0.1 & 101 & 37 & 3.5 & 96 \\
\hline
\end{tabular}

${ }^{a}$ Rating scale: $1=$ no, $2=$ rather no, $3=$ rather yes, $4=$ yes, to $5=$ yes, very strongly. ${ }^{*} p<0.05$, ** $p<0.01$ (one-tailed t-test, mean above 2.5)

In addition, Table 2 provides the data for the degree of which the professional work of graduates of ETH Environmental Sciences is related to sustainability with regard to societal sectors and the size of the organization. As we see, all sectors significantly demonstrate relatedness to sustainability $(>2.5)$, with work in the NGO sector being most strongly related to sustainability. We obtain similar results for organizations of various sizes, with the exception of organizations with between 100 and 249 employees. 
The distribution of work time devoted to sustainability (last three columns) for company size and sectors is similar to that of the general relatedness to sustainability (second to fourth column).

The second part (2) of the Specialists Hypothesis stated that in general, the graduates are somehow concerned with sustainability in their professions. As Table 1 shows, the graduates' work is at least somewhat related to sustainability in 16 out of 19 fields of professional activity (binomial test, $p<0.01$ ). On average, the professionals rate this sustainability relation with a mean of 3.1 , which lies a little but significantly above $2.5(\mathrm{n}=525, \mathrm{t}=9.4, p<0.01)$. The third part (3) of the Specialists Hypothesis refers to a long-term increase of sustainability engagements. We see that if professionals are engaged in sustainability (relatedness of work to sustainability $>2.5$ ), the engagement increases throughout their career $(\mathrm{n}=271, \mathrm{t}=10.3, p<0.01)$. Thus, also parts (2) and (3) of the Specialists Hypothesis are confirmed by the data.

\subsubsection{Sustainability Expertise in Foreign Professional Fields: Pioneers}

The Pioneers Hypothesis stated that (1) even in professional fields with low sustainability we will find graduates whose work is (considerably) related to sustainability and (2) these graduates have an increased influence on sustainability concerns in their organizations in the course of their careers. As shown by Table 1, there are three professional fields with low ratings of the relatedness or professional activities to sustainability. These fields are banks/insurances, in the health sector and in other public services. The Pioneers Hypothesis can be confirmed in both parts. In professional fields with low sustainability there are at least 24 graduates whose work is considerably related to sustainability (self-assessments $>2.5$ on a five point scale). As shown in Table 3 , their perceived personal influence has significantly increased in the course of their careers ( $>$ threshold $2.5 ; \mathrm{n}=24, \mathrm{t}=2.7, p<0.05$ ).

Table 3. Pioneers Hypothesis: Perceived increase in personal influence on sustainability issues in professional fields currently showing a weak relation to sustainability $(<$ threshold 2.5).

\begin{tabular}{cc}
\hline $\begin{array}{c}\text { Weak relation of individual } \\
\text { professional activity to } \\
\text { sustainability }(<\text { threshold 2.5) }\end{array}$ & $\begin{array}{c}\text { Considerable relation of } \\
\text { individual professional activity to } \\
\text { sustainability }(>\text { threshold 2.5) }\end{array}$ \\
\hline
\end{tabular}

Change of perceived influence on sustainability through time ${ }^{\text {a }}$ $1.8^{* *}(\mathrm{n}=51) \quad 3.0^{*}(\mathrm{n}=24)$

${ }^{\text {a }}$ Rating scale: $1=$ strong decrease, $2=$ slight decrease, $3=$ slight increase, $4=$ strong increase, $5=$ very strong increase. $* p<0.05, * * p<0.01$ (one-sample t-test, mean above/below 2.5)

The Pioneers Hypothesis does not imply that the graduates of ETH Environmental Sciences were the very first environmental experts to enter these fields. Swiss insurance companies started to employ environmental specialists long before ETH establishes the educational program in Environmental Sciences. The Pioneers Hypothesis only points out that in professional fields such as banking where the work of graduates of ETH Environmental Sciences is usually not linked to sustainability we find graduates with a enduring work relation to sustainability. Among them are real pioneers such as the members of the former start-up teams of SAM, one of the very first independent sustainability rating 
firms for asset management, or INrate, an asset rating firm that is based on an integrative and explicitly ethical understanding of sustainability.

\subsubsection{Influence: Leaders}

As Table 4 displays, 27 graduates hold top managerial positions ( $9 \%$ of the employed graduates). If we combine upper and highest managerial levels, 51 graduates are leaders, that is about $17 \%$ of the employed graduates or $10 \%$ of all surveyed graduates.

We see in Table 4 that the contribution to sustainability is correlated with the job position. The second to the fifth columns of Table 4 display the (self-) assessments of the best practice examples on four dimensions: strength of effect; sustainability aspects covered (as defined by the Swiss sustainability strategy); integration of the three sustainability dimensions of ecological, economic and social sustainability; and the monitoring of the sustainability effects. All these measures increase significantly with the job position (Spearman rho, $p<0.01$ ). Comparing with graduates in medium or lower positions, graduates in upper or highest positions show higher sustainability ratings in all of the four aspects measured. In addition, we see that the professionals in upper and highest positions consider the Environmental Sciences education as valuable for their career (for upper and higher level $\mathrm{t}=2.6$, $p<0.01)$. Thus data confirmed the Leaders Hypothesis.

Table 4. Leaders Hypothesis: Promotion of sustainability by graduates in leadership positions (self-employed graduates are not covered in the table).

\begin{tabular}{|c|c|c|c|c|c|c|}
\hline $\begin{array}{l}\text { Managerial } \\
\text { position }\end{array}$ & $\mathbf{n}$ & $\begin{array}{c}\text { Strength of } \\
\text { the } \\
\text { sustainability } \\
\text { contribution } \\
\end{array}$ & $\begin{array}{l}\text { Aspects } \\
\text { covered } \\
\text { (out of 15) }\end{array}$ & $\begin{array}{c}\text { Integration } \\
\text { of the } 3 \\
\text { dimensions } \\
(\%) \\
\end{array}$ & $\begin{array}{c}\text { Monitoring } \\
\text { of sustain- } \\
\text { ability effects } \\
(\%) \\
\end{array}$ & $\begin{array}{c}\text { "Environmental } \\
\text { Sciences } \\
\text { education } \\
\text { valuable?" } \mathrm{b} \\
\end{array}$ \\
\hline 1 None & 140 & 2.8 & 5.4 & 41 & 25 & 3.2 \\
\hline 2 Lower level & 68 & 2.9 & 5.9 & 43 & 28 & 3.6 \\
\hline 3 Mid-level & 48 & 3.1 & 6.3 & 53 & 35 & 3.5 \\
\hline 4 Upper level & 24 & 3.6 & 6.3 & 67 & 54 & 3.7 \\
\hline $\begin{array}{l}5 \text { Highest (e.g., } \\
\text { CEO) }\end{array}$ & 27 & 3.6 & 6.8 & 63 & 41 & 3.7 \\
\hline $\begin{array}{l}\text { Correlation with } \\
\text { job position } \\
\text { (Spearman rho) }\end{array}$ & & $0.22 * *$ & $0.16 * *$ & $0.16 * *$ & $0.15 * *$ & $0.20 * *$ \\
\hline $\begin{array}{r}\text { Comparison } 4 \& 5 \\
v s .1,2 \& 3 \text { (t-test) }\end{array}$ & & $p<0.01$ & $p<0.05$ & $p<0.01$ & $p<0.01$ & $p<0.01$ \\
\hline
\end{tabular}

\section{Qualitative Study: Social Capital Analysis}

\subsection{General Approach}

The social capital analysis focused on the transmission of knowledge produced by the ETH Environmental Sciences into the Swiss society and economy. The research question was: Which were 
the transmission paths from Environmental Sciences into the Swiss social systems? The institutional settings that support the transmission - such as networks - were considered as social capital, as they "facilitate coordination and cooperation for mutual benefit" [6].

The study was based on a social systems approach. Social systems are considered more or less separate fields of social discourse and production, the core social systems being economy, politics, law, and science. The concept of social systems was introduced by the prominent sociologist Parsons [35]. Luhmann [11], who further elaborated the social systems approach, pointed to the difficulties of mutual penetration of social systems, particularly in the context of ecological concerns. The analysis of the economy as a social system was based on the national innovation system concept [36].

The social capital analysis covered the Swiss social systems with the exception of the science system, as ETH Zurich conducted a separate international scientific evaluation of its Environmental Sciences department. For the social capital analysis, we distinguished three social sub-systems: (i) economy (the private sector), (ii) politics/public administration (the public sector), and (iii) civil society. The legal system is usually considered a system of its own. However, we assumed that, in the case of sustainability, law and politics are closely linked [12] and therefore subsumed law under politics/public administration. Furthermore, we differentiated civil society from the public sector because of the high importance of NGOs and other associations whose reach extends far beyond political decision-making. In addition, civil society also includes autonomous professional associations, professions being-besides the national governments - co-actors in the development of universitybased scientific disciplines [37]. Thus, civil society is considered a social (sub-)system of its own for the purposes of our study.

\subsection{Methods}

Figure 2 provides an overview of the research methodology of the qualitative study. Table 5 shows the research design for the interviews. The study covered three social sub-systems: the private and public sectors and the Swiss civil society. The study comprised four steps, sketched in Figure 2.

(I) The first step consisted in identifying the key players of each sub-system and the organizations that should be interviewed. For this, three system interviews were conducted with representatives of the involved sub-systems. Additional context information came from the 2001-survey on Swiss environmental professionals [38], an interview with the head of the ETH Environmental Alumni and updated official statistics for industrial productivity in Switzerland [39].

(II) The second step was to interview the organizations. The standard method applied was structured expert interviews [40]. All interviews were conducted by the first author, the interview guide was similarly structured for all organizations (cf. Annex A). For comparatively complex organizations (e.g., Swiss Re, WWF), the interviews involved individuals from both the management and the project levels. The findings related to human and social capital that occurred in more than one of the interviews were formulated as hypotheses. Findings and hypotheses were consolidated through interviews with top experts from each sub-system, namely the Swiss employers' association (economic system); IDHEAP, the Lausanne-based 
Graduate School of Public Management (public sector); and WWF, the World Wide Fund for Nature (NGOs).

(III) The third step was to aggregate and integrate the findings of the interviews with the results of the quantitative study. To this end, a one-day workshop was conducted with experts from all key players of the involved sub-systems [41]. The expert workshop resulted in the re-definition of the hypotheses as theses on transmission paths of ETH Environmental Sciences into society and economy in Switzerland.

(IV)Finally, the Advisory Board of the ETH Environmental Sciences with representatives of politics and the key Swiss industries discussed and reviewed the results of the studies and the expert workshop. This resulted in slight changes in the crafting of the transmission paths theses and in the definition of future tasks for the ETH Environmental Sciences educational program, documented by a report [27].

Table 5. Research design of the interviews.

\begin{tabular}{|c|c|c|c|}
\hline \multirow[b]{2}{*}{$\begin{array}{l}\text { System- } \\
\text { interview }\end{array}$} & Economy (private sector) & $\begin{array}{l}\text { Politics/public adminis- } \\
\text { tration (public sector) }\end{array}$ & Civil society (NGOs) \\
\hline & Private Consultant (ETH alumnus) & $\begin{array}{l}\text { Head of the Federal } \\
\text { Office for the } \\
\text { Environment (BAFU) }\end{array}$ & $\begin{array}{c}\text { Head of sanu } \\
\text { (Professional school } \\
\text { for sustainability) }\end{array}$ \\
\hline $\begin{array}{c}\text { Key } \\
\text { Players }\end{array}$ & $\begin{array}{l}\text { Planning offices } \\
\text { Knowledge intensive service firms } \\
\text { (consultancy/research) } \\
\text { other Swiss SMEs } \\
\text { Global companies in knowledge } \\
\text { intensive sectors (incl. pharma) } \\
\text { other large enterprises (retail, } \\
\text { transport, etc.) }\end{array}$ & $\begin{array}{ll}- & \text { Politics } \\
& \text { Federal and } \\
& \text { Cantonal } \\
& \text { Administrations } \\
\text { (Environment \& } \\
\text { Planning) }\end{array}$ & $\begin{array}{ll}\cdot & \text { NGOs } \\
\cdot & \text { Professions }\end{array}$ \\
\hline $\begin{array}{l}\text { Organiz- } \\
\text { ations } \\
\text { selected }\end{array}$ & $\begin{array}{ll}\text { - } & \text { Coop [large retailer] } \\
\text { - } & \text { Geberit [sanitary technology } \\
\text { - } & \text { company] } \\
\text { - } & \text { Infras [consulting firm] } \\
\text { - } & \text { Pöyry Infra [engineering firm] } \\
\text { - } & \text { SBB * [Sset management company] } \\
\text { - } & \text { SVU-SIA *[planning offices] } \\
\text { - } & \text { Swiss Re [re-insurance company] } \\
\end{array}$ & $\begin{array}{ll}\text { - } & \text { ARE [Federal } \\
& \text { administration] } \\
\text { - } & \text { BAFU [Federal } \\
& \text { administration] } \\
\text { - } & \text { Berufsregister * } \\
& \text { [Politics }] \\
\text { - } & \text { SBB * }[\text { Politics }] \\
\text { - } & \text { UVEK [Politics }]\end{array}$ & $\begin{array}{ll}- & \text { Berufsregister * } \\
& \text { [Professions }] \\
\text { - } & \text { NZZ [Press }] \\
\text { - } & \text { SVU-SIA * } \\
& \text { [Professions }] \\
\text { - } & \text { WWF }[\text { NGO }]\end{array}$ \\
\hline $\begin{array}{r}\text { Top expert } \\
\text { (institution) }\end{array}$ & Swiss employers' association & IDHEAP & WWF \\
\hline
\end{tabular}

ARE: Federal Office for Spatial Development; BAFU: Federal Office for the Environment; Berufsregister: Swiss Federal Foundation for Professional Qualifications; IDHEAP: Swiss Graduate School of Public Administration; NZZ: Neue Zürcher Zeitung; SAM: Sustainable Asset Management; SBB: Swiss Federal Railways; SVU-SIA: Swiss Association of Environmental Professionals (SVU) within the Swiss Association of Engineers and Architects; UVEK: Federal Department of the Environment, Transport, Energy and Communications; WWF: World Wide Fund For Nature. * appears in two categories. 
Figure 2. Methodology of the qualitative study.

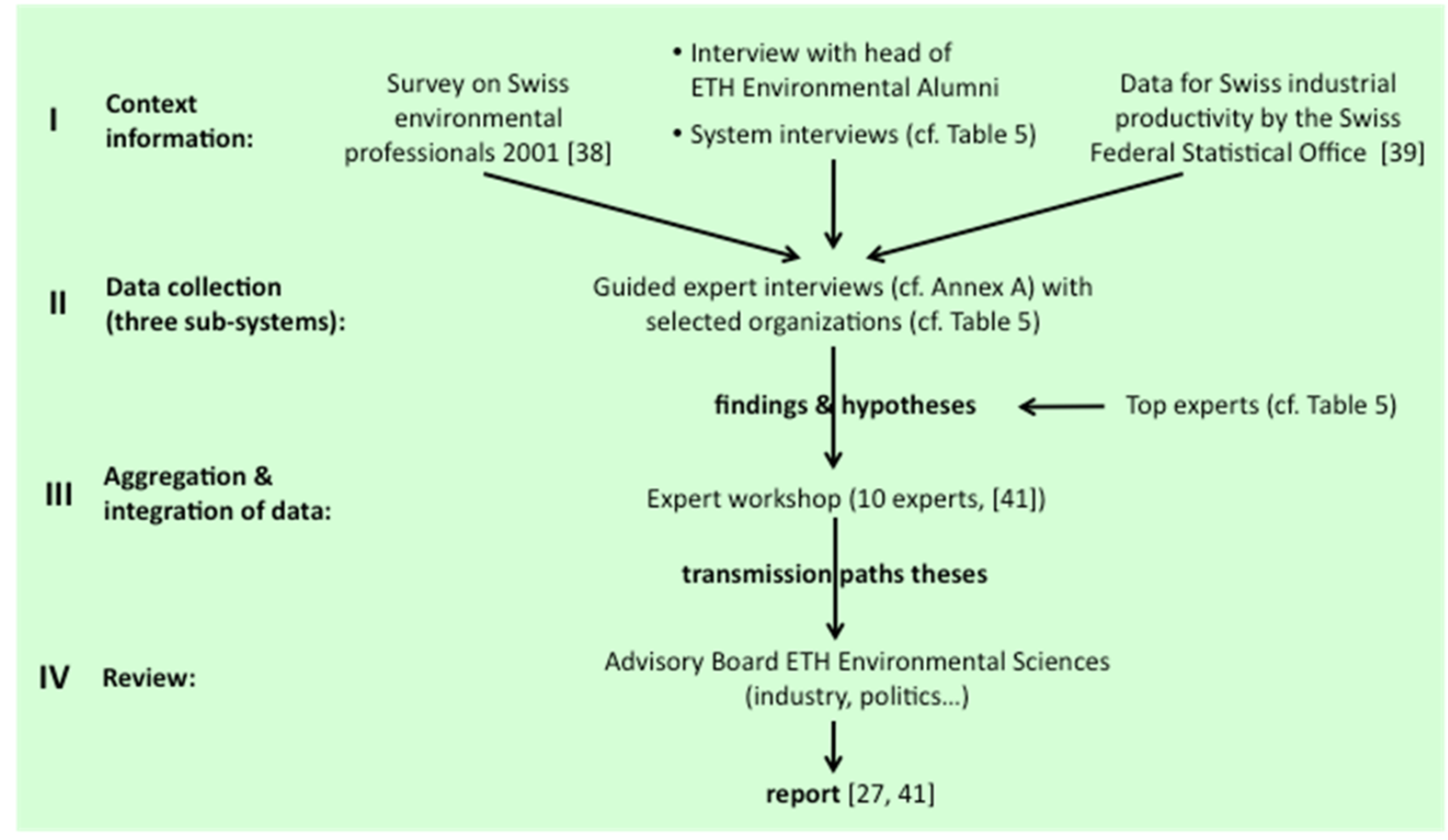

\subsection{Results}

A set of five key transmission paths - as functional forms of social capital — was identified. The interactions between ETH Environmental Sciences and the Swiss social sub-systems were sketched on this basis. In the following we present five transmission path theses (in italics) as they have been formulated as a result of the qualitative study (cf. Figure 2):

\subsubsection{Qualification Profile}

Swiss companies that are global players in a "knowledge-based economy" (banking, insurance, pharmaceutical companies, etc.) and their consulting firms are looking for people with strong analytical skills, excellent communication skills and a willingness towards life-long learning. In this context, the graduates from ETH Environmental Sciences are considered as generalists, competing with physicists in particular.

In contrast, small and medium Swiss enterprises that are not part of the "globalized knowledgeeconomy” (e.g., planning offices, environmental experts, geo-technical firms, etc.) are looking for highly skilled specialists with sufficient practical experience. In this context, graduates from ETH Environmental Sciences are considered as useful specialists.

Thus, the graduates of ETH Environmental Sciences show different qualification profiles depending on the kind of industry and employer. We can assume that there are correspondingly different groups among the graduates. 


\subsubsection{Internalization}

Companies increasingly internalize environmental regulations and tasks in their operating procedures. Initially, they employed environmental experts to implement procedures for environmental protection, reporting, etc. Through internalization, these tasks become a part of the working processes in the operating units. Environmental scientists serve as important promoters or catalysts for this change, thus making themselves partly redundant.

This is consistent with the theory ecological modernization [42] that postulates an increasing internationalization of environmental concerns into day-to-day organizational processes.

\subsubsection{Networks}

Environmental scientists form a growing network, taking over high positions in various fields of Swiss society, science, and economy. The effects are:

- $\quad$ Redirection of the political agenda

- Stimulation of the demand for professional environmental consulting and services

- Increased capabilities to change positions and work (further expanding the network)

The last point corresponds to how Granovetter described weak ties in personal networks [43]. We find such a personal network of graduates of Environmental Sciences, for example, in and around Swiss Re, a big re-insurance company. Further evidence for the stimulation of demand for professional environmental consulting and services (the second point) already resulted from so-called transdisciplinary case studies (see 2.1) that represented integrated consulting for cities, regions and companies and brought follow-up consulting jobs for the involved students of Environmental Sciences. A recent example for the redirection of the political agenda (first point) is the Swiss "stopp-offroader"initiative for a referendum to restrict the use of off road vehicles in Switzerland (in order to mitigate climate change impacts). This was a direct result of traffic research at the ETH Environmental Sciences, put forward by a graduate who is member of the Swiss parliament. This initiative has led to a change in the Swiss $\mathrm{CO}_{2}$-law [44].

\subsubsection{Standardization}

The penetration of well-educated environmental professionals in the labor market and Swiss society enhances intersectoral communication, based on a shared terminology as well as shared concepts and theories. Considering the spectrum ranging from industry to NGOs, this facilitates the "rational" discussion of environmental issues and leads to a standardization of environmental practice and guidance.

One of the most prominent single standardization examples is the eco indicator 99, today a standard tool for life cycle assessment. It was developed by a doctoral student at the ETH Environmental Sciences (in the context of a life cycle assessment research team). 


\subsubsection{Professionalization}

The establishment of ETH Environmental Sciences fostered the professionalization of the field of professional environmental services, e.g., in the context of the re-organization and strengthening of the professional association. However, in Switzerland, environmental sciences are publicly perceived as part of higher education but not as scientific discipline that may be linked to a profession of its own.

The contribution of ETH Environmental Sciences to the professionalization of the field environmental services has been described in several studies [45]. Though there is a divide between educational program and scientific reputation. ETH Zurich is known for climate research, water research, etc. and not for integrative, interdisciplinary approaches - which is a prime goal of the education program.

\subsubsection{Interactions Between the Social Sub-Systems}

Figure 3 depicts the interactions between the social systems and the ETH Environmental Sciences, as they have become evident in the interviews. Three types of interactions are represented. Under perceptions, for instance, ETH Environmental Sciences understands the skill requirements of global companies such as Swiss Re (“analytical skills \& communication”) and Swiss SMEs recognize the profile of ETH graduates. Second, under linkages, for instance, graduates and faculty of ETH Environmental Sciences support environmental NGOs and, as another example, the political administration contracts private consultancies to conduct studies. Third, under standardization, for instance, research at ETH Environmental Sciences ("D-UWIS-Science") defines standards used in the study program, while politics defines environmental standards for Swiss SMEs through legislation. The figure shows the important role of networks, standardization, and the qualification profile. Of course, such a set of interactions is not special for one of the top global universities and probably correct for many more science departments.

Figure 3. Interactions between the Swiss social systems and ETH Environmental Sciences.

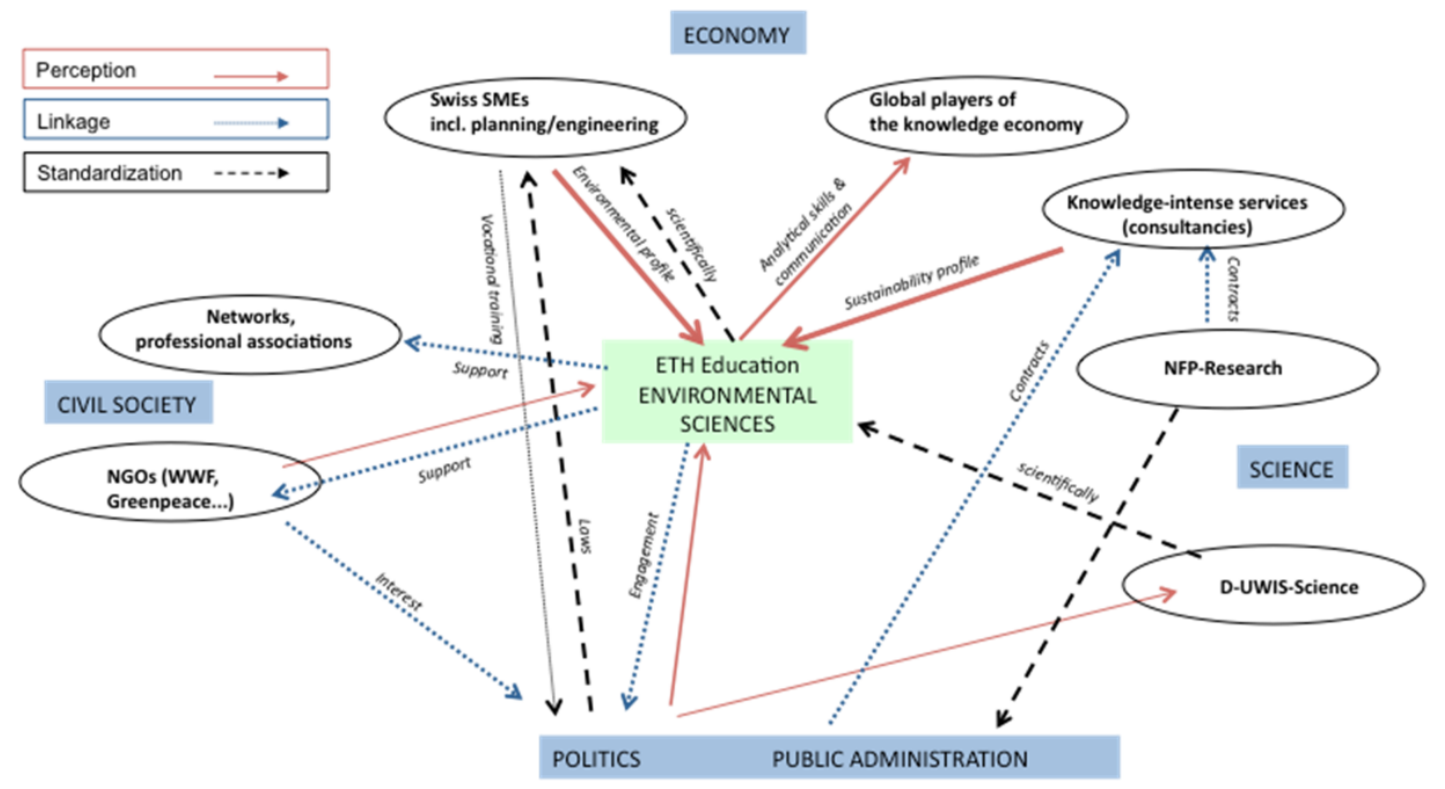

Notes: D-UWIS-Science: ETH Environmental Sciences; ETH: Swiss Federal Institute of Technology; NFP: Swiss National Research Programmes; NGOs: Non-governmental organizations; SMEs: Small- and medium-sized enterprises. 


\section{Discussion and Conclusions}

The outreach study aimed at answering two questions: What was - in terms of human and social capital - the contribution of the Environmental Sciences educational program to sustainability in Switzerland? What does this case teach us about functional forms of human and social capital of sustainability outreach in general? We operationalized sustainability outreach as a specific national contribution to human and social capital [46], taking reference to OECD initiatives to assess educational outputs $[1-3,8]$. The results were:

- With regard to human capital: our study revealed the sustainability contributions of the graduates of ETH Environmental Sciences, differentiating three types of human capital (specialists, pioneers, leaders);

- With regard to social capital: the study identified five transmission paths for ETH Environmental Sciences into the Swiss social systems (qualification profile, internalization, networks, standardization, professionalization).

The outreach study combined a quantitative study on human capital with a qualitative study on the social capital contribution. Many of the findings correspond to similar research in related fields. For instance, internalization as a transmission path is also described in the context of ecological modernization [42]; the role of networks as social capital was particularly emphasized by Granovetter [43]; and professionalization as a link between education and social systems has been highlighted by several authors $[47,48]$. However, our study delivered new insight into the role of standardization for sustainability outreach and the transmission of science education into society.

The final discussion will re-examine how the assessment of sustainability outreach can be based on studying human und social capital (5.1). We conclude with some methodological considerations (5.2).

\subsection{Sustainability Outreach Based on Human and Social Capital}

Our data confirmed the distinction of several functional forms of human capital, i.e., three types of "wealth embodied in labour, skills and knowledge" [3]. We distinguished between specialists, pioneers, and leaders. The pioneers prepare the field in a professional world that is rather "hostile" towards sustainability objectives. The specialists work as experts in a great variety of Swiss industries; they are primarily sought by medium and small-sized firms and support processes of internalization and the dissemination of standards. Leaders are particularly sought by international companies that are players in the globalized economy. In contrast to the specialists, leaders are generalists working, for instance, with global insurance companies to define a corporate sustainability strategy in the face of climate change.

Leadership can also be considered a form of social capital [49]. This was reflected in the quantitative study, with leaders being addressed because of the institutionalized form of influence they represent. However, leadership was not mentioned in the qualitative study as a particular transmission path. The Environmental Sciences education program might be too young to be publicly perceived as a leading societal institution for the advancement of sustainability in Switzerland. A common topic in the interviews, however, was the impact of Environmental Sciences on the standardization of environmental concern in Switzerland, standardization being an example of norms as social capital [7]. Krigsvoll, 
Fumo and Morbiducci [50] showed the important role of international standardization for sustainability in construction. Our study revealed how, at the Swiss national level, graduates of Environmental Sciences helped to disseminate a shared terminology for discussing and taking decisions on environmental issues. Standardization thus facilitates “coordination and cooperation"-in Putnam's terms [6] — and contributes to the formalization of modern life [51].

While revealing the important role of standardization, the outreach study also showed limitations. In particular, Environmental Sciences in Switzerland is (still) perceived by the public as an educational program but not as an integrated science. That is why the political or public advice function did not play a major role in our interviews. The public also likely attributes expert advice to, for instance, climate change research or hydrology but not the Environmental Sciences program-despite the fact that the program does indeed educate hydrologists and climate researchers. This fragmented perception might even increase in the coming years, as the ETH Environmental Sciences education program has been transformed from a single diploma course program into a Master's study program with various majors. The public perception of Environmental Sciences also restrains the further development of the environmental profession in Switzerland. In general, any established profession has to have a clear relation to a—often homonymic — scientific discipline and an academic study program $[37,48]$.

\subsection{Methodological Considerations}

Our study showed how higher education can contribute to sustainability on a national level. We were not so much interested in directly assessing the national sustainability impact - that would have required a sort of sustainability impact assessment [52]. Instead, we studied sustainability outreach in form of supporting intermediary social structures - the functional forms - incorporated by human and social capital [53]. To conceive sustainability contributions as human and social capital aligns with concepts of sustainability that are based on an assessment of resources [54] or the capital stock involved [55]. However, human and social capital might be seen in completely different ways. For instance, the Swiss MONET project (German abbreviation for monitoring of sustainable development) defines the "development and maintenance of human capital" as "collective knowledge and sociocultural heritage [that] should be maintained and increased over the long term" [56]. Our study defined human and social capital by the line of research put forth by the OECD [1,2], linking it to higher education in particular.

In the international realm of science education, developing human capital at a national level has been an explicit political target for the last twenty years. These efforts to develop human capital are in general linked to investments in social capital, for instance, the development of national systems of accreditation and continuing regular evaluation of education [8]. More generally, research on expert performance teaches us that the optimization of human capital in terms of excellent people - in sports as well as in science - today requires high investments in social capital in terms of professionalized supporting institutions, e.g., for high-level training [33]. Therefore, the success of sustainability-oriented science education might be assessed not only with regard to human capital but also with regard to the development of social capital. In addition to former initiatives towards an accounting of human capital [1], our study might contribute to an accounting of further educational outcomes in the form of 
social capital, as "[s]olid evidence on outcomes is among the best ways to justify continued public investments in education" [8].

A key to the further development of this human and social capital based outreach assessment will be linking it to an evaluation of single elements of an educational program [15,57]. How do specific courses or theories contribute to the overall sustainability impact of an educational program? In the case of the ETH Environmental Sciences, critical elements could be the transdisciplinary case studies [17] or the systems thinking model [27] on which the educational program is based on. This might require rethinking the role of sciences and science education in the context of environmental and global change [58,59].

\section{References and Notes}

1. Measuring What People Know: Human Capital Accounting for the Knowledge Economy; Organisation for Economic Co-operation and Development (OECD): Paris, France, 1996.

2. Human Capital Investment: An International Comparison; Organisation for Economic Co-operation and Development (OECD): Paris, France, 1998.

3. Glossary of Statistical Terms: Human Capital; Organisation for Economic Co-operation and Development (OECD): Paris, France, 2001. Available online: http://stats.oecd.org/glossary/ detail.asp?ID=1264 (accessed on 24 June 2011).

4. Šlaus, I.; Jacobs, G. Human capital and sustainability. Sustainability 2011, 3, 97-154.

5. Bourdieu, P. Outline of a Theory of Practice; Cambridge University Press: Cambridge, UK, 1977.

6. Putnam, R.D. Bowling alone: America's declining social capital. J. Democr. 1995, 6, 65-78.

7. Glossary of Statistical Terms: Social Capital; Organisation for Economic Co-operation and Development (OECD): Paris, France, 2003. Available online: http://stats.oecd.org/glossary/ detail.asp?ID=3560 (accessed on 24 June 2011).

8. Investing in Human and Social Capital: New Challenges. Chairs Summary; OECD Education Ministerial Meeting: Paris, France, 2010. Available online: www.oecd.org/dataoecd/53/16/ 46335575.pdf (accessed on 24 June 2011).

9. Becker, G.S. Human Capital, 3rd ed.; The University of Chicago Press: Chicago, IL, USA, 1993.

10. Mieg, H.A. The Social Psychology of Expertise; Lawrence Erlbaum Associates: Mahwah, NJ, USA, 2001.

11. Luhmann, N. Ecological Communication; The University of Chicago Press: Chicago, IL, USA, 1989.

12. Bussmann, W. Gewässerschutz und kooperativer Föderalismus in der Schweiz; Haupt: Bern, Switzerland, 1981.

13. Cf. for instance the Swiss MONET project for the monitoring of sustainable development in Switzerland, or the fusion of the main associations of professional environmental engineers and environmental professionals (ecologists) in 2002.

14. Frischknecht, P.M. Environmental science education at the Swiss Federal Institute of Technology (ETH). Water Sci. Technol. 2000, 41, 31-36. 
15. Frischknecht, P.M.; Imboden, D. Environmental sciences education at the Swiss Federal Institute of Technology (ETH) Zürich and at other Swiss universities. Environ. Sci. Pollut. Res. 1995, 2, 56-59.

16. Hansmann, R. Linking the components of a university program to the qualification profile of graduates: The case of a sustainability-oriented Environmental Science curriculum. J. Res. Sci. Teach. 2009, 46, 537-569.

17. Scholz, R.W.; Tietje, O. Embedded Case Study Methods: Integrating Quantitative and Qualitative Knowledge; Sage Publications: Thousand Oaks, CA, USA, 2002.

18. Scholz R.W.; Steiner, R.; Hansmann R. The role of internship in higher education in environmental sciences. J. Res. Sci. Teach. 2004, 41, 24-46.

19. Müller-Herold U.; Frischknecht, P.M. Wegleitung für den Studiengang Umweltnaturwissenschaften; Department of Environmental Sciences/Swiss Federal Institute of Technology: Zurich, Switzerland, 1989.

20. Environment Experts: Bachelor and Master Programmes in Environmental Sciences; D-UWIS Environmental Sciences, Ed; Department of Environmental Sciences/Swiss Federal Institute of Technology: Zurich, Switzerland, 2009.

21. Lepenies, W. Benimm und Erkenntnis: Über die notwendige Rückkehr der Werte in die Wissenschaften; Suhrkamp: Frankfurt am Main, Germany, 1997; pp. 43-44.

22. Perspektive Grosses Moos: Wege zu einer nachhaltigen Landwirtschaft, Fallstudie 1994; Scholz, R.W., Koller, T., Mieg, H.A., Schmidlin, C., Eds.; Verlag der Fachvereine: Zürich, Switzerland, 1995.

23. Zentrum Zürich Nord, Stadt im Aufbruch: Bausteine für eine nachhaltige Stadtentwicklung, Fallstudie 1996; Scholz, R.W., Bösch, S., Mieg, H.A., Stünzi, J., Eds.; Verlag der Fachvereine: Zürich, Switzerland, 1997.

24. Industrieareal Sulzer-Escher Wyss, Umwelt und Bauen: Wertschöpfung durch Umnutzung, Fallstudie 1995; Scholz, R.W., Bösch, S., Mieg, H.A., Stünzi, J., Eds.; Verlag der Fachvereine: Zürich, Switzerland, 1996.

25. Scholz, R.W.; Lang, D.J.; Wiek, A.; Walter, A.I.; Stauffacher, M. Transdisciplinary case studies as a means of sustainability learning. Int. J. Sustain. Higher Educ. 2006, 7, 226-251.

26. De la Vega-Leinert, A. C.; Stoll-Kleemann, S.; O’Riordan, T. Sustainability science partnerships in concept and in practice: A guide to a new curriculum from a European perspective. Geogr. Res. 2009, 47, 351-361.

27. Brunner, S.H.; Frischknecht, P.; Hansmann, R.; Mieg, H.A. Environmental Sciences Education Under the Microscope: Do Graduates Promote a Societal Change Towards Sustainability? Department Environmental Sciences/Swiss Federal Institute of Technology: Zurich, Switzerland, 2010. Available online: http://www.env.ethz.ch/docs/survey/index_EN (accessed on 30 June 2011).

28. Jacobs, J.K.; Kawanaka, T.; Stigler, J.W. Integrating qualitative and quantitative approaches to the analysis of video data on classroom teaching. Int. J. Educ. 1999, 31, 717-724.

29. Stephens, J.C.; Hernandez, M.E.; Román, M.; Graham, A.C.; Scholz, R.W. Higher education as a change agent for sustainability in different cultures and contexts. Int. J. Sustain. Higher Educ. 2008, $9,317-338$. 
30. Scott, W.A.H.; Gough, S.R. Sustainability, learning and capability: Exploring questions of balance. Sustainability 2010, 2, 3735-3746.

31. The Cambridge Handbook of Expertise and Expert Performance; Ericsson, K.A., Charness, N., Feltovich, P., Hoffman, R.R., Eds.; Cambridge University Press: Cambridge, UK, 2006.

32. Feltovich, P.J.; Ford, K.M.; Hoffman, R.R.; Eds. Expertise in Context: Human and Machine; AAAI Press: Menlo Park, CA, USA, 1997.

33. Mieg, H.A. Two factors of expertise? Excellence and professionalism of environmental experts. High Abil. Stud. 2009, 20, 91-115.

34. Schweizerischer Bundesrat. Strategie Nachhaltige Entwicklung 2002. Bericht des Schweizerischen Bundesrates vom 27. März 2002; Schweizerischer Bundesrat: Bern, Switzerland, 2002.

35. Parsons, T. The Social System; Free Press: New York, NY, USA, 1964.

36. National Systems of Innovation; Lundvall, B.Å., Ed.; Pinter: London, UK, 1992.

37. Abbott, A. Linked ecologies: States and universities as environments for professions. Sociol. Theory 2005, 23, 245-274.

38. De Sombre, S.; Woschnack, U.; Naef, M.; Mieg. H.A. Professionelle Umwelt-Tätigkeiten in der Schweiz 2001, 2nd ed.; Department Environmental Sciences/Swiss Federal Institute of Technology: Zurich, Switzerland, 2010. Available online: http://e-collection.ethbib.ethz.ch/view/ eth:25707 (accessed on 17 November 2011).

39. Produktion, Umsätze; Bundesamt für Statistik: Neuchâtel, Switzerland, 2010. Available online: http://www.bfs.admin.ch/bfs/portal/de/index/themen/06/03/blank/data.html (accessed on 17 November 2011).

40. Mieg, H.A.; Brunner, B. Experteninterviews: Reflexionen zur Methodologie und Erhebungstechnik. Schweiz. Z. Soziol. Swiss J. Sociol. 2004, 30, 199-222.

41. Mieg, H.A. The Impact of the Establishment of Environmental Sciences at the ETH on Swiss Economy and Society: An Evaluation Study; Department Environmental Sciences/Swiss Federal Institute of Technology: Zurich, Switzerland, 2010. Available online: http://www.env.ethz.ch/ docs/survey/index_EN (accessed on 30 June 2011).

42. Environment and Global Modernity; Spaargaren, G., Mol, A.P.J., Buttel, F.H., Eds.; Sage: London, UK, 2000.

43. Granovetter, M. The strength of weak ties. Am. J. Soc. 1973, 78, 1360-1380.

44. Für eine menschenfreundliche Mobilität Web Site. Available online: http:// www.menschenfreund licher.ch/stoppoffroader/ (accessed on 17 November 2011).

45. Mieg, H.A. Professionalization and professional identities of environmental experts: The case of Switzerland. J. Integr. Environ. Sci. 2008, 5, 41-51.

46. The focus of this article lies on human and social capital and not on the understanding of sustainability transported by the ETH Environmental educational program. However, the quantitative data also allowed for an analysis and evaluation of the best practice examples, as shown by Hansmann, R. et al. The set of professional activities could be described through three dimensions (p. 283): (1) nature protection and protection of humans, (2) product and process development, (3) education and communication. Though nature protection and environmental concerns dominate, graduates of ETH Environmental Sciences are also contributing to economic and social sustainability. For instance, some of professional practice examples-such as 
promoting intercultural gardens - have a focus on the aspect of "sustaining cultural and societal values".

47. Professional Learning; Boshuizen, H.P.A., Bromme, R., Gruber, H., Eds.; Kluwer: Dordrecht, The Netherlands, 2004.

48. Mieg, H.A. Professionalisation. In Handbook of Technical and Vocational Education Research; Rauner, F., Maclean, R, Eds.; Springer: Dordrecht, the Netherlands, 2008; pp. 502-508.

49. Walker, B.H.; Gunderson, L.H.; Kinzig, A.P.; Folke, C.; Carpenter, S.R.; Schultz, L. A handful of heuristics and some propositions for understanding resilience in social-ecological systems. Ecol. Soc. 2006, 11, article 13:1-article 13:15.

50. Krigsvoll, G.; Fumo, M.; Renata Morbiducci, R. National and international standardization (International Organization for Standardization and European Committee for Standardization) relevant for sustainability in construction. Sustainability 2010, 2, 3777-3791.

51. Stinchcombe, A.L. When Formality Works; The University of Chicago Press: Chicago, IL, USA, 2001.

52. SIA Sustainability Impact Assessment; PricewaterhouseCoopers with the funding of the EU Commission: Neuilly-sur-Seine, France, 2011. Available online: http://www.sia-acp.org (accessed on 19 September 2011).

53. The expert workshop (see Figure 2) also developed a quantitative assessment of the sustainability outreach of the ETH Environmental Science educational program (in the sense of integrated sustainability). The average impact of ETH Environmental Sciences (graduates) on integrative sustainable development of social systems in Switzerland was rated as 0.85 $(-1=$ negative impact, $0=$ no impact, $1=$ positive impact, $2=$ distinct positive impact $)$. A comparatively high impact resulted for environmental consulting and planning offices (1.2), whereas a lower impact was found in politics (0.7) and Swiss SMEs (0.7).

54. Mieg, H.A. Sustainability and innovation in urban development: Concept and case. Sustain. Dev., in press.

55. Handbook of National Accounting-Integrated Environmental and Economic Accounting 2003; United Nations, European Commission, International Monetary Fund, Organisation for Economic Co-operation and Development, and World Bank: New York, NY, 2003. Available online: unstats.un.org/unsd/environment/seea2003.pdf (accessed on 19 September 2011).

56. Sustainable Development-MONET; Bundesamt für Statistik: Neuchâtel, Switzerland, 2011. Available online: http://www.bfs.admin.ch/bfs/portal/en/index/themen/21/02/ind9.indicator. 72707. 927. html (accessed on 24 June 2011).

57. Hansmann, R.; Mieg, H.A.; Frischknecht, P. Qualifications for contributing to sustainable development: A survey of Environmental Sciences graduates. Gaia 2010, 19, 278-286.

58. The New Production of Knowledge; Gibbons, M., Limoges, C., Nowotny, H., Schwartzman, S., Scott, P., Trow, M., Eds.; Sage: London, UK, 1994.

59. Transdisciplinarity: Joint Problem Solving Among Science, Technology, and Society; Thompson Klein, J., Grossenbacher-Mansuy, W., Häberli, P., Bill, A., Scholz, R.W., Weltli, M., Eds.; Birkhäuser: Basel, Switzerland, 2001. 


\section{ANNEX A: Interview Guides \\ [translated from German]}

\section{Private Sector}

Core business:

- What is the core business of your company/your industry? What are the value chains?

- Changes last 5-10 years?

- How is your company/your industry related to sustainability?

Personnel:

- Which occupations are working in your company/your industry?

- Changes last 5-10 years?

Visibility of graduates of ETH Environmental Sciences:

- Are there graduates of ETH Environmental Sciences (further option: environmental experts) employed in your company/your business?

- How are these graduates perceived with regard to (further option: from the view of human resource management, how important is for your company ...)

○ sustainability (know-how, strategic thinking)?

○ working as a generalist $v s$. specialist?

○ a systems view (integrative, multi-disciplinary, multi organizational levels...)?

Specific contribution of ETH Environmental Sciences:

- Would your company/your industry be different without contributions by ETH Environmental Sciences with regard to

$\circ$ individuals,

○ institutions,

○ ideas?

\section{Public Sector}

Core function:

- What is the core function of your institution? What are your key processes?

- Changes last 5-10 years?

- How is your institution related to sustainability? 
Personnel:

- Which occupations are working in your institution?

- Changes last 5-10 years?

Visibility of graduates of ETH Environmental Sciences:

- Are there graduates of ETH Environmental Sciences (further option: environmental experts) employed in your institution?

- How are these graduates perceived with regard to (further option: viewing the range of duties and individual capabilities of your institution, how important is...)

○ sustainability (know-how, strategic thinking)?

○ working as a generalist $v s$. specialist?

○ a systems view (integrative, multi-disciplinary, multi organizational levels...)?

Specific contribution of ETH Environmental Sciences:

- Would your institution be different without contributions by ETH Environmental Sciences with regard to

$\circ$ individuals,

○ institutions,

$\circ$ ideas?

\section{Civil Society}

Core responsibility:

- What is the responsibility of your organization? What are your key contributions to civil society?

- Changes last 5-10 years?

- How is your organization related to sustainability?

Personnel:

- Which occupations are working in your organization?

- Changes last 5-10 years?

Visibility of graduates of ETH Environmental Sciences:

- Are there graduates of ETH Environmental Sciences (further option: environmental experts) employed in your organization?

- How are these graduates perceived with regard to (further option: from the view of human resource management, how important for your organization is...)

○ sustainability (know-how, strategic thinking)? 
- working as a generalist $v s$. specialist?

○ a systems view (integrative, multi-disciplinary, multi organizational levels...)?

Specific contribution of ETH Environmental Sciences:

- Would your organization/civil society be different without contributions by ETH

Environmental Sciences with regard to

$\circ$ individuals,

○ institutions,

○ ideas?

(C) 2012 by the authors; licensee MDPI, Basel, Switzerland. This article is an open access article distributed under the terms and conditions of the Creative Commons Attribution license (http://creativecommons.org/licenses/by/3.0/). 